Purdue University

Purdue e-Pubs

Open Access Theses

Theses and Dissertations

Summer 2014

\title{
The nature of parental involvement in middle school: Examining nonlinear associations
}

Elizabeth A. Wehrspann

Purdue University

Follow this and additional works at: https://docs.lib.purdue.edu/open_access_theses

Part of the Education Commons, Psychology Commons, and the Sociology Commons

\section{Recommended Citation}

Wehrspann, Elizabeth A., "The nature of parental involvement in middle school: Examining nonlinear associations" (2014). Open Access Theses. 703.

https://docs.lib.purdue.edu/open_access_theses/703

This document has been made available through Purdue e-Pubs, a service of the Purdue University Libraries. Please contact epubs@purdue.edu for additional information. 


\section{PURDUE UNIVERSITY \\ GRADUATE SCHOOL \\ Thesis/Dissertation Acceptance}

This is to certify that the thesis/dissertation prepared

By Elizabeth A. Wehrspann

Entitled

The Nature of Parental Involvement in Middle School: Examining Nonlinear Associations

For the degree of

Master of Science

Is approved by the final examining committee:

Aryn Dotterer

Shawn Whiteman

Douglas Powell

To the best of my knowledge and as understood by the student in the Thesis/Dissertation Agreement. Publication Delay, and Certification/Disclaimer (Graduate School Form 32), this thesis/dissertation adheres to the provisions of Purdue University's "Policy on Integrity in Research" and the use of copyrighted material.

\section{Aryn Dotterer}

Approved by Major Professor(s):

Approved by: Douglas Powell $07 / 10 / 2014$ 

THE NATURE OF PARENTAL INVOLVEMENT IN MIDDLE SCHOOL: EXAMINING NONLINEAR ASSOCIATIONS

\author{
A Thesis \\ Submitted to the Faculty \\ of \\ Purdue University \\ by \\ Elizabeth A. Wehrspann \\ In Partial Fulfillment of the \\ Requirements for the Degree \\ of \\ Master of Science
}

August 2014

Purdue University

West Lafayette, Indiana 
TABLE OF CONTENTS

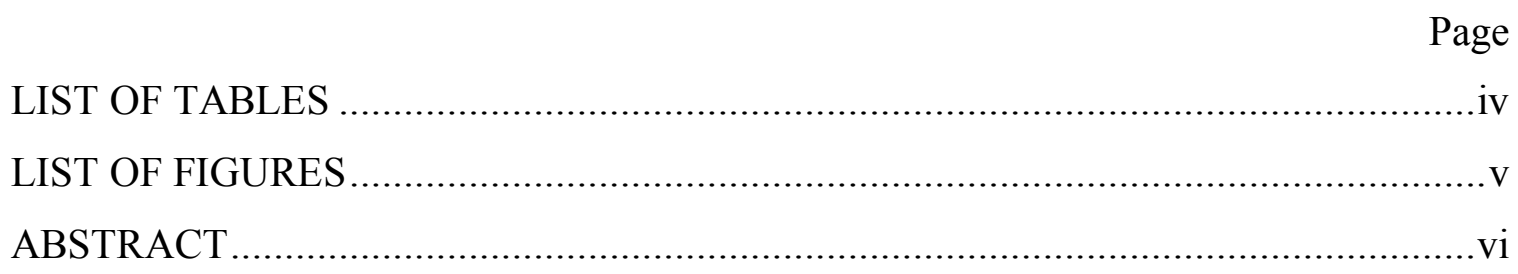

CHAPTER 1. INTRODUCTION .................................................................

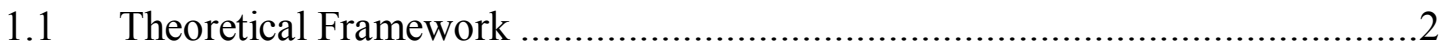

1.2 Parental Involvement and Links to Academic Achievement and Motivation....7

1.2.1 Parental Involvement and Academic Achievement ................................

1.2.2 Parental Involvement and Intrinsic Motivation ...................................11

1.3 Age-Related Changes in Academic Outcomes and Involvement ..................13

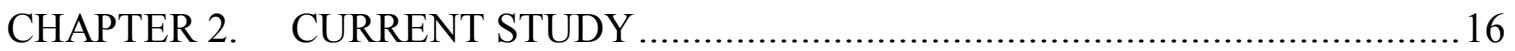

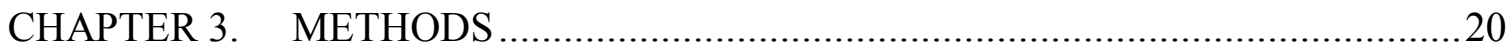

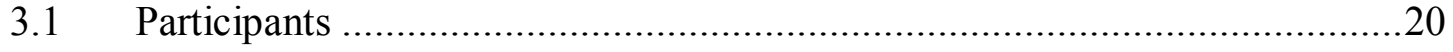

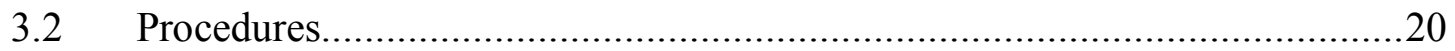

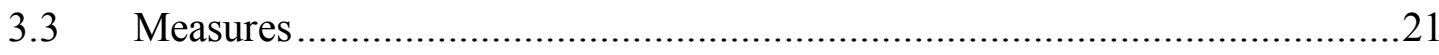

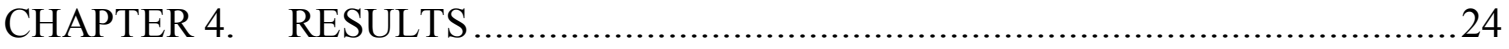

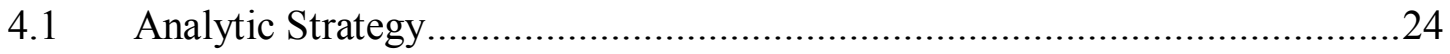

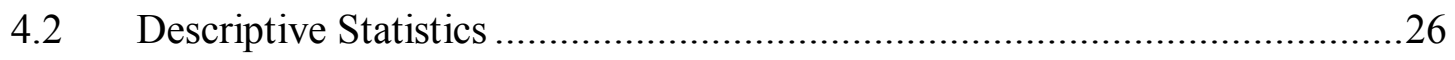

4.3 How is Parental Involvement Related to Academic Achievement? ...............26

4.4 How is Parental Involvement Related to Intrinsic Motivation? ....................28

4.5 Does Adolescent Age Moderate the Effect of Parental Involvement on Academic Achievement and Motivation? ................................................29

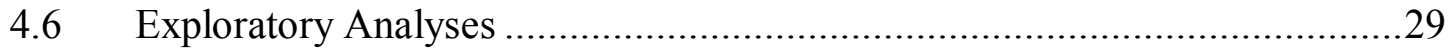


4.6.1 Are Different Facets of Home-based Involvement Associated with Academic Outcomes Differently?

4.6.2 Does Race Moderate the Associations Among Parental Involvement, Academic Achievement, and Intrinsic Motivation?................................31

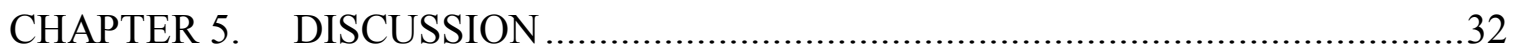

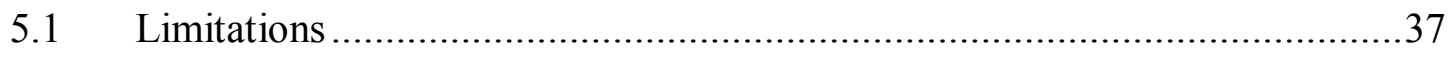

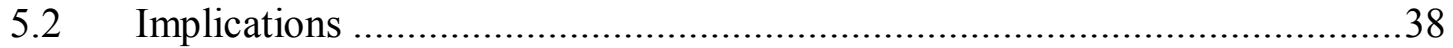

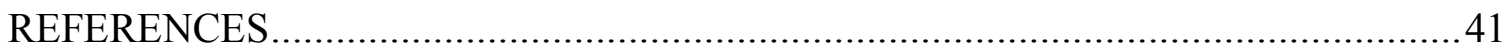
APPENDICES

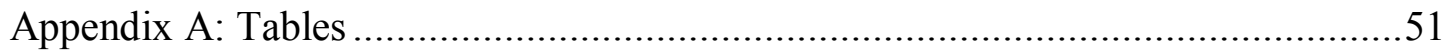

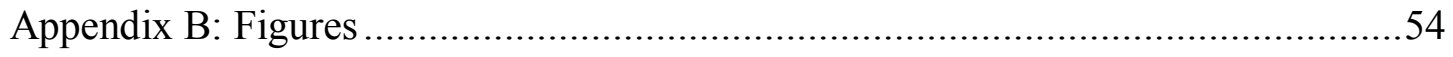

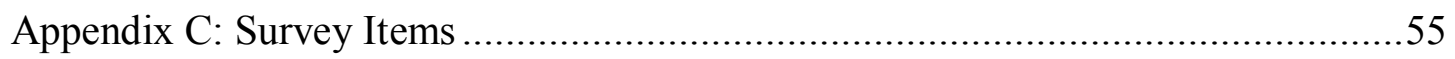




\section{LIST OF TABLES}

Table Page

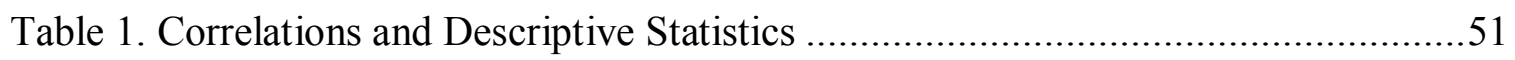

Table 2. Summary of Regression Analyses for Home-based Involvement ....................52

Table 3. Summary of Regression Analyses for Academic Socialization ........................53 


\section{LIST OF FIGURES}

Figure Page

Figure 1. Academic Socialization and Intrinsic Motivation .......................................54 


\begin{abstract}
Wehrspann, Elizabeth A. M.S., Purdue University, August 2014. The Nature of Parental Involvement in Middle School: Examining Nonlinear Associations. Major Professor: Aryn Dotterer.

Middle school is a time during which the importance of school performance and academic motivation increases, yet actual adolescent achievement and motivation tend to decline during this period. Extent research and theory highlight the importance of parental involvement in education for adolescents, as most work shows that parent involvement is positively related to academic achievement and motivation. However, there are also many mixed findings regarding the link between specific types of involvement (i.e., home-based involvement and academic socialization) and these outcomes. Further, little work has been done to examine the possible age-related differences in these associations. Guided by Self-Determination Theory and theories of parental involvement, the current study examined the nonlinear associations among parental involvement, academic achievement, and intrinsic motivation in an effort to illuminate possible explanations for these mixed findings. Participants included 106 adolescents (20\% white/Caucasian, $80 \%$ non-white) in grades six through eight who attended a Midwestern urban middle school. Adolescents responded to an in-school survey during the spring semester and reported on intrinsic motivation, parents' homebased involvement, and academic socialization. Academic achievement was measured using adolescents' spring grades obtained from official report cards. Findings provided
\end{abstract}


limited evidence for nonlinear associations between parental involvement and academic outcomes. Contrary to expectations, there were no links between parental involvement and academic achievement. A positive linear association between home-based involvement and intrinsic motivation was observed. As hypothesized, there was a nonlinear association between academic socialization and intrinsic motivation, suggesting that greater levels of parental involvement may not always be beneficial for adolescents' intrinsic motivation. Findings provided no evidence of age-related differences in these associations. Possible explanations and implications of these findings for future research are discussed. 


\section{CHAPTER 1. INTRODUCTION}

Adolescent academic achievement and motivation are critical issues in the United States. According to the National Assessment of Educational Progress (NAEP), 65\% of eighth graders scored partially or below proficient on math and reading assessments in 2011 (Institute of Education Sciences, 2011). Further, studies have shown that intrinsic motivation, a factor positively associated with adolescent school success, declines during adolescence (Lepper, Corpus, \& Iyengar, 2005). Academic achievement and motivation are important factors during adolescence because they are related to adolescents' longterm career aspirations and positive developmental outcomes (Barnard, 2004; Hill et al., 2004; Schunk, Pintrich, \& Meece, 2008). Therefore, schools and policymakers are continually seeking ways to improve both (No Child Left Behind [NCLB], 2002).

Parental involvement has gained widespread attention from policymakers, researchers, and professionals as an important predictor of adolescent academic success

and intrinsic motivation (e.g., Fan \& Chen 2001; Gonzalez-DeHass, Willems, \& Holbein, 2005; NCLB, 2002; Van Voorhis, 2011). Scholars have examined the links between parental involvement, academic achievement, and motivation and generally found that involvement is positively related to academic achievement and motivation for adolescents (e.g., Hill \& Tyson, 2009; Jeynes, 2012; Marchant, Paulson, \& Rothlisberg, 2001; Van Voorhis, 2011). Greater amounts of involvement may not always be beneficial, however, 
as scholars have also reported that involvement is unrelated to academic outcomes and at times, even negatively related to youth's academic outcomes (Pomerantz, Moorman, \& Litwack, 2007). It may be that parents' uses of strategies that best meet the unique needs of adolescents, such as a growing desire for autonomy, are most advantageous for adolescents (Hill \& Taylor, 2004; Hoover-Dempsey \& Sandler, 1995; Pomerantz et al., 2007).

Previous studies have not fully investigated the extent to which involvement, particularly in the form of home-based involvement and academic socialization, is positively associated with academic achievement and motivation. Further, few studies have examined how these links may be different for younger versus older adolescents (Muller, 1998), which is an important oversight given the age-related changes in adolescent academic motivation and achievement (Corpus, McClintic-Gilbert, \& Hayenga, 2009; Dotterer, Lowe, \& McHale, 2013). The current study sought to fill these gaps in the literature by examining the relation between home-based involvement, academic socialization, academic achievement, and intrinsic motivation. More specifically, this study examined whether the associations between parental involvement (home-based involvement and academic socialization) and adolescents' academic outcomes (academic achievement intrinsic motivation) were nonlinear. The present study also examined whether age moderated these associations.

\subsection{Theoretical Framework}

The construct of parental educational involvement can be generally defined as “...parents' work with schools and with their children to benefit their children's 
educational outcomes and future success" (Hill et al., 2004, p. 1491). Theorists have emphasized the multidimensionality of parental involvement and its links to a wide variety of student outcomes, including academic achievement and motivation (e.g., Hoover-Dempsey, Ice, \& Whitaker, 2009). The many types of involvement have been defined in a variety of ways. For example, Epstein (2001) proposed six types of involvement: parenting (parents creating a positive home environment for the child), communicating (home-school communication), volunteering (parent support at school), learning at home (parents helping with student schoolwork), decision-making (parentteacher collaboration in making decisions), and collaborating with the community (families, schools, and communities working together). Hoover-Dempsey and Sandler (1995) classified involvement in four ways - parental expression of goals, values, and expectations, parental involvement at home, parental involvement at school, and parentteacher communication. Despite slight differences in operationalizing involvement, there is consensus that parental involvement is multidimensional and includes different types of involvement at home, at school, and via parents' communication strategies with both their child and child's teacher (Epstein, 2001; Hoover-Dempsey et al., 2009; HooverDempsey \& Sandler, 1995; Grolnick \& Slowiaczek, 1994).

Some forms of involvement are direct, such as helping with homework, whereas other forms are indirect, such as expressing an interest in school or communicating the value of an education (Hill \& Chao, 2009). The present study focused on two different forms of involvement in order to investigate both direct and indirect types. Specifically, this study examined academic socialization, which is communicating expectations for 
education and its value or utility, as well as parental involvement at home, which includes checking homework and helping with schoolwork.

Theorists have proposed several mechanisms through which parental involvement strategies are linked to adolescent outcomes. For example, Grolnick and Slowiaczek (1994) posited that parental involvement, defined in this framework as the allocation of resources provided to a child that relate to academia, benefits students academically by improving their perceived competence, self-regulation (which includes intrinsic motivation), and perceptions of control. Grolnick and Slowiaczek also emphasized the child's perception of involvement as a mechanism through which involvement influences academic outcomes; “...the child must experience the resources for them to have their influence" (p.238). This highlights the importance of recognizing the child as an active participant in parents' involvement strategies. Hoover-Dempsey and Sandler (1995; Hoover-Dempsey et al., 2009) posited that parents influence their children through encouragement, modeling, reinforcement, and instruction. Parents encourage by openly supporting activities related to school, they model by demonstrating values for and the importance of an education, they reinforce by providing positive feedback for behaviors that benefit adolescents, and they instruct by teaching children learning strategies as well as explicit academic concepts. Importantly, it has also been noted that these mechanisms may help explain why some involvement strategies are more appropriate for adolescents than other strategies (Hoover-Dempsey et al., 2009). In particular, less intrusive strategies such as encouragement and modeling meet developmental needs of adolescents, such as increasing autonomy, whereas checking homework may be perceived by adolescents as 
controlling or intrusive, which can undermine autonomy (Hoover-Dempsey et al., 2009; Karbach, Gottschling, Spengler, Hegewald, \& Spinath, 2013).

Multiple theorists have noted the changing patterns of involvement as children age and the increasing need for developmentally appropriate types of involvement to maximize benefits for adolescents (Epstein, 2001; Hoover-Dempsey \& Sandler, 1995; 2005). In her overlapping spheres theory of parental involvement, Epstein (2001) described three spheres of influence - the family, school, and community - that are constantly shifting in the ways they impact each other and that overlap differently as a child ages. For example, school and family spheres may overlap differently during the elementary school years compared to the middle school years, such that the family-school connection is stronger in elementary school (Epstein, 2001). Hoover-Dempsey and Sandler (1995) also noted the changing needs of children as they age, such as an increasing need for autonomy and the importance of a good fit between these needs and parents' involvement strategies. "Children moving into adolescence become more... independent and less interested in accepting obvious help, praise, or even expressions of interest from parents...” (p. 324). A good fit may maximize the potential for positive impact, whereas strategies that undermine adolescent autonomy and personal identity may weaken involvement efforts (Hoover-Dempsey \& Sandler, 1995; Hoover-Dempsey et al., 2009).

Ryan and Deci’s (2000) Self-Determination Theory also provides a framework for understanding the importance of autonomy-supportive involvement strategies for adolescents. Self-Determination Theory posits that "... social contexts that support people's being competent, related, and autonomous will promote motivated action" (Deci, 
Vallerand, Pelletier, \& Ryan, 1991, p. 332). In contrast, when people feel forced or pressured into action, they will be less responsive than when they feel they are making choices on their own (Wehmeyer, Abery, Mithaug, \& Stancliffe, 2003). Contexts promoting competence, autonomy, and relatedness have been linked to positive social functioning and personal well-being (Ryan \& Deci, 2000). Contexts that are not supportive of competence, autonomy, and relatedness have been negatively related to a person's motivation, development, socialization and performance (Deci et al., 1991).

Parental involvement is one such context that has the potential to support or undermine adolescent competence, relatedness, and autonomy. For example, parents may use involvement strategies at levels that support an adolescent's sense of selfdetermination and are linked to beneficial outcomes such as academic motivation and achievement (Ryan \& Deci, 2000). In contrast, parents may use strategies at levels that lead to adolescents feeling forced into actions or beliefs, therefore undermining their sense of autonomy and subsequent positive outcomes. This same pattern may emerge for different types of involvement: strategies such as home-based involvement, when used at high levels, may undermine autonomy more so than strategies such as academic socialization, because home-based strategies represent more direct forms of involvement (Hill \& Tyson, 2009; Hoover-Dempsey et al., 2009).

These theories of parental involvement, along with Self-Determination Theory, informed the present study by providing a foundation for understanding the links between parental involvement and adolescent academic outcomes, as well as the possible nonlinear relation between parental involvement and adolescent motivation and academic achievement. Although there is some evidence that various types of parental involvement 
are positively linked to achievement and motivation (e.g., Hill \& Tyson, 2009; Jeynes, 2012; Marchant, et al., 2001; Van Voorhis, 2011), high levels of these same forms of involvement may be negatively related to school outcomes because they strip adolescents of their autonomy (Pomerantz et al., 2007).

\subsection{Parental Involvement and Links to Academic Achievement and Motivation}

Adolescence is a time when youth experience rapid biological, social, and cognitive changes (Archibald, Graber, \& Brooks-Gunn, 2006; Casey, Getz, \& Galvan, 2008; Steinberg, 2001). These changes often coincide with a transition to middle school and declines in academic motivation and achievement, self-confidence, school grades, and increases in test anxiety (Eccles \& Roeser, 2009). At the same time, the importance of academic achievement and motivation increases. Middle school is a crucial time for adolescents as they select courses and are placed in course tracks that may influence future class achievement and career decisions (Eccles \& Harold, 1996; Wang \& Goldschmidt, 2003). There is clearly a mismatch between the increased importance of academic achievement and declines in adolescent performance and motivation in middle school. As such, adolescence is a crucial developmental period to study parental involvement and its links to academic adjustment (Gutman \& Midgley, 2000).

\subsubsection{Parental Involvement and Academic Achievement}

There has been a plethora of research conducted on parental involvement as it relates to a variety of academic outcomes (e.g., Anguiano, 2004; Epstein, 2001; Hill \& Chao, 2009; Hill et al., 2004; see Pomerantz et al., 2007 for review), but only recently has 
the focus of empirical study shifted from children to adolescents (Hill \& Taylor, 2004). Studies that have examined parental involvement during adolescence have demonstrated that even though the amount of parental involvement tends to decline as children age (Spera, 2005), it continues to be an important factor for adolescents (Hill et al., 2004; Hoover-Dempsey et al., 2009). For example, in their longitudinal study of $7^{\text {th }}$ and $8^{\text {th }}$ graders in the United States and China, Cheung and Pomerantz (2012) found that parental involvement was related to increased academic achievement over time.

As the number of studies focusing on adolescents has increased, it has become clear that parental involvement is a multi-dimensional construct that may manifest differently as children age (Hill \& Tyson, 2009; Yan \& Lin, 2005). Home-based strategies, which may be important for elementary students (Domina, 2005; Hill \& Tyson, 2009), have been inconsistently related to adolescents' academic achievement. For example, Karbach, Gottschling, Spengler, Hegewald, and Spinath (2013) investigated the links between two types of home-based involvement and academic achievement. Homebased involvement strategies were categorized as autonomy-supportive strategies (e.g., parents encouraging their adolescents to find an answer by themselves) and achievementoriented control (e.g., parents scolding adolescents when they received bad grades). After accounting for general cognitive ability, autonomy-supportive strategies of involvement were unrelated to academic achievement, whereas control strategies were negatively related to achievement. Spera (2006) also reported that home-based involvement, which included helping with schoolwork and knowing adolescents' grades, was unrelated to academic achievement for $7^{\text {th }}$ and $8^{\text {th }}$ grade students. In contrast, Van Voorhis (2011) reported positive links between parental home-based involvement (e.g., parent- 
adolescent interactions with homework) and academic achievement among middle school students.

The association between academic socialization and academic achievement is also unclear. For example, Marchant, Paulson, and Rothlisberg (2001) reported positive links between academic socialization and achievement for fifth and sixth grade students, as did Hill and Tyson in their 2009 meta-analysis of parental involvement during middle school. In contrast, Desimone (1999) reported both positive and negative associations between academic socialization (i.e., communicating about high school and post-high school plans) and adolescent school performance across racial/ethnic and socioeconomic groups. Findings were also mixed within racial/ethnic groups and socioeconomic groups. For example, for African American students, communicating about high school was associated with a lower GPA, whereas talking about post-high school plans was associated with a higher GPA. It is important to note, however, that mixed findings may have been explained by a difference in who reported involvement (parent or adolescent). In their study of African-American middle school and high school students, Sirin and Rogers-Sirin (2004) reported mixed findings for different facets of academic socialization; there was no association between parents' educational values and academic achievement, but adolescents had higher levels of achievement when their parents had higher expectations.

Further, the extant literature is inconclusive as to which type of involvement academic socialization versus home-based involvement - is more strongly associated with academic achievement. In studies comparing different types of involvement simultaneously, such as meta-analyses by Fan and Chen (2001), as well as Hill and Tyson 
(2009), home-based involvement - defined as homework help, help with school work, and creating a supportive learning environment - had weaker associations with academic outcomes compared to academic socialization strategies. Academic socialization strategies, such as communicating parental expectations for education and its value, were found to have the strongest links to academic achievement. In contrast, Jeynes' (2003) meta-analysis, which focused on minority students, found that home-based strategies, rather than academic socialization, were most strongly associated with academic achievement. Though, it is important to note that Jeynes' (2003) meta-analysis included youth in grades K-12, which may explain the difference in findings.

The many mixed findings linking home-based involvement and academic socialization with academic achievement have prompted further investigation as to why these types of involvement are inconsistently linked to academic achievement during adolescence. One proposed explanation for these inconsistent findings is the reactive hypothesis, which posits that parents may become involved in response to adolescents' prior school performance (Hoover-Dempsey et al., 2009; Pomerantz, et al., 2007). Previous empirical studies have been inconclusive in substantiating this explanation, however. In his 2012 study of eighth graders, McNeal used cross-lagged analyses to investigate parental response to performance over three years. Contradicting the reactive hypothesis, findings showed that as performance decreased, parents became less involved. Parents of higher achieving adolescents, however, became more involved over time. This may be evidence of a different type of reaction from parents than described by the reactive hypothesis; adolescents who are high-performing may elicit more involvement from parents than those who are low-performing. Thus, the present study attempted to 
tease apart these effects by controlling for adolescents' perceptions of academic competence.

\subsubsection{Parental Involvement and Intrinsic Motivation}

Intrinsic motivation is a person's drive to seek out new experiences, challenges, and learning opportunities because they are inherently rewarding (Ryan \& Deci, 2000). It is a critical component of adolescent academic success because it is a key factor in knowledge and skill development that is amenable to change (Ryan \& Deci, 2000). Intrinsic motivation has been positively linked to task persistence, perception of competence and performance, and negatively linked to anxiety (Ryan \& Deci, 2000; Schunk et al., 2008). Recent research highlights the importance of environmental influences, such as parental involvement, which can enhance or hinder intrinsic motivation (Fan \& Williams, 2010; Ryan \& Deci, 2000).

Scholars have noted that parental involvement strategies are linked to adolescent motivation, but no clear conclusions have been drawn regarding the benefits of homebased involvement for adolescents (e.g., Fan \& Williams, 2010; Ginsberg \& Bronstein, 1993; Gonzalez-DeHaas et al., 2005). For example, Spera (2006) reported that increased parental involvement with school work was significantly related to increases in interest in school and school motivation for $7^{\text {th }}$ and $8^{\text {th }}$ grade adolescents. However, Ginsburg and Bronstein (1993) found that $5^{\text {th }}$ graders had lower motivation the more their mothers were involved with homework (i.e., reminding adolescents about homework or checking homework). 
Few studies have explored the links between academic socialization and intrinsic motivation (Gonzalez-DeHaas et al., 2005; Marchant, Paulson, \& Rothlisberg, 2001). In their study of fifth and sixth graders, Marchant, Paulson, and Rothlisberg (2001) found that adolescent reports of their parents' expressing the importance of an education was associated with an increase in adolescent motivation. Fan and Williams (2010) examined math and English motivation among $10^{\text {th }}$ grade students. Their findings showed that parents' reports of advising adolescents (e.g., helping their adolescent make plans for college) and communication of aspirations were positively linked to both math and English motivation. These two studies have begun to provide evidence for a link between parental involvement and motivation, but were limited by sample population (the majority of participants being White/Caucasian in the Marchant, Paulson, and Rothlisberg study) and operationalization of motivation (a focus on subject-specific motivation in the Fan and Williams study, which also only included high school students). These two studies also focused solely on linear associations between parental involvement and adolescent motivation. Therefore, due to these limitations, and in response to a call to researchers to further examine these associations (Fan \& Williams, 2010), the present study analyzed nonlinear links between academic socialization and adolescents' intrinsic motivation.

In summary, there are many inconsistent findings in the literature regarding parental involvement and its links to academic achievement and intrinsic motivation. These inconsistent findings are evidence of the need to further investigate these links. One explanation for these mixed findings may be that parental involvement is associated with academic achievement and intrinsic motivation in a nonlinear way. In particular, 
mixed findings may be the result of the misguided assumption that greater amounts of home-based involvement and academic socialization will always be beneficial for adolescents (Pomerantz et al., 2007). Greater amounts of involvement from parents may inadvertently undermine adolescent autonomy and be negatively associated with outcomes, even if they are intended to benefit adolescents. Examining nonlinear effects, which has not been the focus of previous studies, may help clarify the true nature of the association between involvement and academic outcomes, such that moderate levels of involvement may be beneficial for adolescents, whereas high or low levels of involvement may not be beneficial for adolescents.

\subsection{Age-Related Changes in Academic Achievement, Motivation, and Involvement}

Age is an important factor to consider when studying the associations between parental involvement, academic achievement, and intrinsic motivation, as it has been linked to all three constructs. Declines in academic achievement and intrinsic motivation during adolescence have been well established in extant literature (Barber \& Olsen, 2004; Corpus et al., 2009; Dotterer et al., 2013; Gottfried, Fleming, \& Gottfried, 2001). Declines in academic achievement have been connected to the transition to middle school, but have also been found over time, regardless of school transition (Barber \& Olsen, 2004; Gutman \& Midgley, 2000). For example, Barber and Olsen (2004) conducted a longitudinal study of adolescents from $5^{\text {th }}$ grade to $8^{\text {th }}$ grade and found that school grades declined each year, even after the students transitioned to middle school. Dotterer, Lowe, and McHale (2013) reported similar findings in their longitudinal study of African 
American youth; there was a significant decline in grade point average over time for both boys and girls.

Age is also related to levels of intrinsic motivation. Scholars have reported within-year declines as well as long-term differences in motivation between middle childhood and adolescence (Corpus et al., 2009; Gottfried et al., 2001; Hayenga \& Corpus, 2010). For example, in their cross-sectional study of $3^{\text {rd }}$ through $8^{\text {th }}$ grade students, Corpus, McClintic-Gilbert, and Hayenga (2009) reported lower mean levels of intrinsic motivation for older students versus younger students. Within-year decreases in motivation were most pronounced for adolescents. Further, in an eight-year longitudinal assessment of motivation, Gottfried, Fleming, and Gottfried (2001) reported declines in intrinsic motivation over time.

Scholars have noted that levels of parental involvement also decline as children age (Hill \& Taylor, 2004; Hoover-Dempsey et al., 2009; Milgram \& Toubiana, 1999; Spera, 2005). Milgram and Toubiana (1999), for example, reported lower levels of parental involvement with sixteen-year-olds when compared to thirteen-year-olds. However, few studies have specifically examined whether the links between parental involvement and academic outcomes vary based on a child's age. One study that did investigate these links, found that age moderated the association between parental involvement and mathematics achievement such that there was a stronger association between involvement and achievement for younger students ( $8^{\text {th }}$ graders $)$ versus older students $\left(12^{\text {th }}\right.$ graders) (Muller, 1998). This study focused on home-based strategies, including parent-adolescent communication regarding schoolwork, as well as household 
rules and structure, but did not investigate other facets of involvement such as academic socialization.

Taken together, research suggests that there are age-related declines in academic achievement, motivation, and parental involvement. It is not clear, however, how the links between parental involvement and academic motivation and academic achievement differ as a function of age. As adolescents get older, they have a growing desire for autonomy (Hoover-Dempsey \& Sandler, 1995), such that parental involvement efforts that undermine this autonomy may be more detrimental for older adolescents than younger adolescents. Yet, the one study that has examined age as a moderator of the relation between involvement and academic achievement suggests that the opposite is true: there were weaker links between involvement and academic achievement for older students (Muller, 1998). This study examined only math achievement and included high school students, so findings may be qualified by both the outcome and population studied. To date, no studies have investigated age differences in the link between parental involvement and intrinsic motivation. The scant research examining age-related differences in the association between multiple facets of parental involvement and adolescent academic outcomes highlights the importance of more thoroughly investigating these associations. 


\section{CHAPTER 2. CURRENT STUDY}

The current study aimed to make a significant contribution to the literature through its investigation of nonlinear associations among parental involvement, academic achievement and intrinsic motivation. Although scholars have noted that parental involvement is positively linked to academic achievement and intrinsic motivation, mixed findings in the literature relating home-based involvement and academic socialization to achievement and motivation justified further investigation of these dimensions of involvement during adolescence (e.g., Hill \& Taylor, 2004). Examining nonlinear associations is particularly important as higher levels of involvement may not always benefit adolescents (Pomerantz et al., 2007) because it can undermine adolescents' growing need for an autonomy-supportive environment (Hoover-Dempsey \& Sandler, 1995; Ryan \& Deci, 2000). Further, there may be age-related differences in the links between involvement and academic motivation and achievement that have not been fully explored in extant literature.

Previous studies have also found that adolescent girls consistently outperform adolescent boys in school, particularly when academic achievement is measured using school grades (e.g., Duckworth \& Seligman, 2006; Pomerantz, Altermatt, \& Saxon, 2002). Additionally, scholars have noted differences in the relation between parental involvement and academic achievement and motivation due to adolescent race and parent 
education levels (e.g., Desimone, 1999; Hill et al., 2004; Hill \& Tyson, 2009; Yan \& Lin, 2005). Previous studies have also noted that parental involvement behaviors may be in response to adolescents' prior performance (Pomerantz et al., 2007). Therefore, gender, race, parent education level, and adolescents' perceived academic competence were included as control variables in the present investigation.

The current study sought to address the noted gaps in literature and enhance the understanding of the associations among involvement, academic achievement, and motivation for adolescents of different ages. More specifically, the present study examined the following questions and hypotheses:

Question 1: How is parental involvement (i.e., home-based involvement and academic socialization) related to middle school students' academic achievement?

Hypothesis 1: The relation between home-based involvement and academic achievement will be nonlinear such that the positive association between home-based involvement and achievement will be attenuated at high levels of home-based involvement.

Hypothesis 2: The relation between academic socialization and academic achievement will be nonlinear such that the positive association between academic socialization and achievement will be attenuated at high levels of academic socialization. Question 2: How is parental involvement (i.e., home-based involvement and academic socialization) related to middle school students' intrinsic motivation?

Hypothesis 3: The relation between home-based involvement and intrinsic motivation will be nonlinear such that the positive association between home-based 
involvement and intrinsic motivation will be attenuated at high levels of home-based involvement.

Hypothesis 4: The relation between academic socialization and intrinsic motivation will be nonlinear such that the positive association between academic socialization and intrinsic motivation will be attenuated at high levels of academic socialization.

Question 3: Is there a difference in the strength of the relation between parental involvement and academic achievement for academic socialization versus home-based involvement?

Hypothesis 5: The nonlinear association between parental involvement and academic achievement will be stronger for home-based involvement than academic socialization; the positive association between involvement and achievement will be more strongly attenuated for home-based involvement than academic socialization. Question 4: Is there a difference in the strength of the relation between parental involvement and intrinsic motivation for academic socialization versus home-based involvement?

Hypothesis 6: The nonlinear association between parental involvement and intrinsic motivation will be stronger for home-based involvement than academic socialization; the positive association between involvement and motivation will be more strongly attenuated for home-based involvement versus academic socialization. Question 5: Is the relation between parental involvement (i.e., home-based involvement and academic socialization) and academic achievement moderated by adolescent age? 
Question 6: Is the relation between parental involvement (i.e., home-based involvement and academic socialization) and intrinsic motivation moderated by adolescent age?

Due to the limited evidence from previous studies, no a priori hypotheses were offered regarding age as a moderator in the relation between parental involvement and academic achievement and motivation. 


\section{CHAPTER 3. METHODS}

\section{1 $\quad$ Participants}

Participants were adolescents $(N=106)$ from a public, Title I, Midwestern urban middle school. Fifty-nine percent of adolescents were female. Thirty-five adolescents were in sixth grade ( $33 \%$ of the sample), 45 were in seventh grade $(42 \%)$ and 26 were in eighth grade (25\%). Fifty-two percent of participants were Black or African American, $19 \%$ were multiracial, $20 \%$ were White/Caucasian, $7 \%$ were Hispanic or Latino, and 2\% were Asian. Fifty-three percent of adolescents reported their mothers' education level as a college degree or higher, $18 \%$ indicated some college, and 29\% indicated high school diploma or less. Fifty-three percent of adolescents reported their fathers' education level as a college degree or higher, $18 \%$ indicated some college, and $29 \%$ indicated high school diploma or less.

\subsection{Procedure}

Data for this study were drawn from a larger study investigating school and family experiences of urban youth. Participants were recruited at school registration and via letters mailed to their homes. Following parental and adolescent consent, adolescents completed a self-report survey at school in the fall and in the spring. Adolescents who were absent from school on the day of data collection were mailed a survey. The 
subsample of participants for the current study included only those adolescents for whom spring semester letter grades were available.

\section{3 $\quad$ Measures}

Parental involvement. Parental involvement was measured in the spring, and was operationalized as academic socialization and home-based involvement. Academic socialization was measured with items adapted from Murdock's (1999) Economic Value of Education to assess parents' socialization of educational values. Using a five-point scale, $(1=$ Strongly disagree, $5=$ Strongly agree $)$ participants responded to eight items such as "My parents tell me that an education will help me earn a good living." A mean score was calculated such that higher scores indicated more academic socialization $(\alpha$ $=.71)$. Home-based involvement was measured using a six-item scale. Adolescents responded to items regarding parents' home-based involvement strategies such as helping with schoolwork. Adolescents responded using a three-point scale $(1=$ Never, $3=$ Always $)$ for mothers and fathers separately. Adolescent reports of mother and father involvement were significantly correlated $(r=.42, p<.001)$ and a total home-based parental involvement score was calculated by averaging the two scores such that higher scores indicated more home-based involvement $(\alpha=.84)$.

Intrinsic motivation. To measure intrinsic motivation, adolescents completed a 17-item intrinsic motivation scale during the spring semester that was adapted from previous research (Lepper et al., 2005). Adolescents responded using a five-point scale (1 $=$ Never, $5=$ Always) to items such as "I like hard work because it's a challenge" and "I 
ask questions in class because I want to learn new things." Items were averaged to create a total score, with higher scores indicating more intrinsic motivation $(\alpha=.89)$.

Academic achievement. Academic achievement was measured using adolescents' second semester, spring grades, which were obtained from official school records. Grade Point Average (GPA) was calculated from grades in math, language arts, science, and social studies. Letter grades were assigned numerical scores $(\mathrm{A}=4, \mathrm{~A}-=3.7$ and so forth) such that higher scores signified higher grades.

Perceived academic competence. Using a scale adapted from Jacobs, Lanza, Osgood, Eccles, and Wigfield (2002), adolescents' perceived academic competence was calculated by averaging the sums of adolescents' reports of perceived English and math competence during the fall semester $(\alpha=.85)$. Adolescents responded to five items such as "How good at reading are you?" using a seven-item scale $(1=$ Not at all good, $7=$ Very good).

Adolescent age. Adolescents reported their birth date, and age in years was calculated as of January 1, 2011.

Control variables. Control variables included adolescent gender (male $=0$; female $=1$, adolescent race, parental education level, and adolescents' perceived academic ability. Adolescents were asked to report their race given the following options: Black or African American, White/Caucasian, American Indian, Hispanic or Latino, and Asian or Asian American. A dichotomous race variable was created by categorizing adolescents as white (1) or non-white (0). Parental education was calculated by taking the 
mean of students' reports of their mothers' and fathers' highest level of education, which ranged from "less than a high school degree" (1) to "advanced degrees such as $M S, M D$, or Ph.D." (5). 


\section{CHAPTER 4. RESULTS}

\subsection{Analytic Strategy}

The present study used hierarchical linear regression analyses to examine nonlinear associations between parental involvement and academic outcomes. Following the strategies outlined by Aiken and West (1991), hierarchical regression models were used to examine the nonlinear relation between each type of parental involvement (homebased involvement and academic socialization) as it related to academic achievement and motivation in separate models. Home-based involvement and academic socialization variables were centered at their means $(X)$ and quadratic $\left(X^{2}\right)$ terms were created from the centered variables, respectively. In step 1, control variables were entered. Adolescent gender and adolescent reports of parent education level were not significantly related to intrinsic motivation or academic achievement in any of the models and were therefore dropped from all analyses. Control variables in the final models included adolescent perceived academic competence, race, and age. In step 2, parental involvement (X) was entered. In step 3, the quadratic involvement variable $\left(\mathrm{X}^{2}\right)$ was added. The polynomial coefficient was examined to analyze the shape of the curve. Non-significant polynomials were dropped from the final models.

In order to analyze the strength of the link between each type of involvement and each outcome, the standardized beta coefficients for the significant polynomial terms 
were compared using procedures as outlined by Cohen, Cohen, West, and Aiken (2003). The coefficient for academic socialization as it related to academic achievement was compared to the coefficient for home-based involvement. Then, the coefficient for academic socialization as it related to motivation was compared to the coefficient for home-based involvement.

Moderation analyses examined whether the associations among parental involvement, academic achievement and motivation differed as a function of adolescent age. Adolescent age was centered at its mean and interaction terms were created by calculating the product of the centered age variable and each involvement term (linear and quadratic), creating two 2-way interactions. In step 1, adolescent perceived academic competence and race were entered. In step 2, the centered age variable, the linear involvement variable $(\mathrm{X})$ and the quadratic involvement variable $\left(\mathrm{X}^{2}\right)$ were entered. In step 3, both two-way interactions were entered. A statistically significant change in $R^{2}$ ( $p$ $<.05)$ after the addition of the interaction terms indicated whether or not age moderated the nonlinear relation between involvement and each outcome. If the change in $R^{2}$ was not significant at the $p<.05$ level, the nonlinear interaction term was dropped to examine a linear interaction for each model.

Further analyses examined the assumptions of ordinary least squares regression in each model; assumptions that could be tested were met in each of the models. DF Beta and DF Fit values were calculated to determine if there were any data points with undue influence. Data points were examined for academic achievement and intrinsic motivation models separately, and were considered to have undue influence if they surpassed critical values for both DF Beta and DF Fits. Two cases were identified as having undue 
influence in models for academic achievement. One case was identified as having undue influence in models for intrinsic motivation, and one case was identified as having undue influence in models for both academic achievement and motivation. To maintain a consistent sample, these four outliers were dropped from all analyses.

\subsection{Descriptive Statistics}

Table 1 includes descriptive statistics and correlations for study variables. All variables were normally distributed, as indicated by acceptable values for skew and kurtosis. Adolescents reported a lower mean level of home-based involvement compared to academic socialization. Neither academic socialization nor home-based involvement was significantly correlated with GPA. Both types of involvement were significantly correlated in the expected direction with intrinsic motivation. $t$-tests were used to examine if there were significant differences in academic achievement or motivation based on adolescent gender or race. Males and females did not differ in their mean levels of academic achievement or intrinsic motivation. Non-white adolescents did not differ from White/Caucasian adolescents in their reports of intrinsic motivation.

White/Caucasian adolescents did, however, have significantly higher GPAs $(M=3.49$, $S D=.42)$ than non-white adolescents $(M=2.77, S D=.72), t(100)=-4.39, p<.001$.

\subsection{How is Parental Involvement Related to Academic Achievement?}

Perceived academic competence, race, and age (entered at Step 1) accounted for a significant proportion of variance in GPA, $F(3,98)=21.59, p<.001$. An increase in 
perceived academic competence was associated with a .06 increase in GPA, $\beta=.40, p$ $<.001$, whereas an increase in age was associated with a decrease in GPA, $\beta=-.23, p$ $<.01$. White adolescents had a significantly higher GPA than non-white adolescents, $\beta$ $=.39, p<.001$.

Home-based involvement. The linear association (entered at Step 2) between home-based involvement and GPA was not in the expected direction, nor was it significant after controlling for perceived academic competence, race, and age, $\beta=-.13$, $F(1,97)=2.62$, n.s. The final model included the quadratic effect of home-based involvement, which was not a significant predictor of GPA (see Table 2). These findings did not support hypothesis 1 .

Academic socialization. After controlling for perceived academic competence, race, and age, the linear association (entered at Step 2) between academic socialization and GPA was in the expected direction, but was not significant, $\beta=.06, F(1,97)=.55$, n.s. As can be seen in the final model in Table 3, the quadratic effect of academic socialization was not in the expected direction, nor did it significantly predict academic achievement. Therefore, hypothesis 2 was not supported.

Strength of association. Neither home-based involvement nor academic socialization were associated with adolescent GPA, and therefore standardized beta coefficients were not compared to assess the difference in the strength of the association between each type of involvement and academic achievement. 


\subsection{How is Parent Involvement Related to Intrinsic Motivation?}

When entered in Step 1, the control variables were significant predictors of intrinsic motivation, $F(3,98)=18.14, p<.001$. Perceived academic competence was positively associated with intrinsic motivation, $\beta=.56, p<.001$, such that a one unit increase in academic competence was associated with a .07 unit increase in intrinsic motivation. Adolescent race and age were not associated with intrinsic motivation, $\beta$ $=.06$, n.s. and $\beta=-.13$, n.s., respectively.

Home-based involvement. After controlling for perceived academic competence, race, and age, the linear association (entered at Step 2) between home-based involvement and intrinsic motivation was in the expected direction and was significant, $\beta=.22, F(1$, $97)=7.18, p<.01$. The nonlinear effect of home-based involvement was not significantly related to intrinsic motivation (see Table 2). Hypothesis 3 was partially supported by these findings; there was a positive link between home-based involvement and intrinsic motivation, but this association was not attenuated at high levels of involvement.

Academic socialization. The linear association, entered in Step 2, between academic socialization and intrinsic motivation was in the expected positive direction, but was not significant, $\beta=.08, F(1,97)=1.32$, n.s. There was a significant nonlinear relation between academic socialization and intrinsic motivation after controlling for perceived academic competence, race, and age (see Table 3). Hypothesis 4 was supported by these results. As can be seen in Figure 1, the positive association between academic socialization and intrinsic motivation was attenuated at high levels of academic socialization. 
Strength of association. Although the relation between academic socialization and intrinsic motivation was nonlinear as predicted, the relation between home-based involvement and intrinsic motivation was linear. Therefore, standardized beta coefficients were not compared to assess the difference in the strength of the association between each type of involvement and intrinsic motivation.

\subsection{Does Adolescent Age Moderate the Effect of Parental Involvement on Academic $\underline{\text { Achievement and Motivation? }}$}

Moderation models were analyzed to determine if age moderated the association between parental involvement and each academic outcome. Age did not moderate the association between academic socialization and academic achievement or intrinsic motivation, $F(1,100)=.61$, n.s., and $F(1,100)=.13$, n.s., respectively. Age also did not moderate the association between home-based involvement and academic achievement or intrinsic motivation, $F(1,100)=.01$, n.s., and $F(1,100)=.10$, n.s., respectively.

\subsection{Exploratory Analyses}

4.6.1 Are different facets of home-based involvement associated with academic outcomes differently?

Additional analyses were conducted to explore the links between two facets of home-based involvement and academic outcomes. The home-based involvement scale was split into two subscales: items involving help with homework and items involving other home-based strategies such as knowledge about school. Each subscale included 
three items for mothers and fathers, which were averaged to create a total score for homework help $(\alpha=.76)$ and for other home-based involvement strategies $(\alpha=.75)$. Identical regression models were analyzed to determine the possibly nonlinear links between each type of home-based involvement and each academic outcome (academic achievement and intrinsic motivation).

Homework help. After controlling for perceived academic competence, race, and age, the linear association between homework help and GPA was significant, $\beta=-.16$, $t(101)=-2.02, p<.05$. The nonlinear effect of homework help was not significantly related to GPA, $\beta=.06, t(101)=.67$, n.s. For intrinsic motivation, the linear association was also significant, but was positive, $\beta=.25, t(101)=3.11, p<.01$. The nonlinear effect of homework help was not significantly related to intrinsic motivation, $\beta=.03, t(101)$ $=.35$, n.s.

Other home-based strategies. The linear association between other home-based strategies and GPA was not significant, $\beta=-.08, t(101)=-1.02$, n.s., after controlling for perceived academic competence, race, and age. The nonlinear association between home-based strategies and GPA was also not significant, $\beta=-.00, t(101)=-.01$, n.s. Other home-based strategies were also not significantly associated with intrinsic motivation for the linear and nonlinear models, $\beta=.15, t(101)=1.85$, n.s. and $\beta=.03$, $t(101)=.32$, n.s., respectively

4.6.2 Does race moderate the associations among parental involvement, academic achievement, and intrinsic motivation? 
Using the dummy-coded variable for race, interaction terms were created with each type of parental involvement. Moderation analyses were conducted with each type of involvement for both outcomes; race did not moderate the association between parental involvement (home-based involvement and academic socialization) and academic achievement, $F(1,100)=. .08$, n.s., and $F(1,100)=-.08$, n.s. respectively, nor did it moderate the association between parental involvement (home-based involvement and academic socialization) and intrinsic motivation $F(1,100)=-.13$, n.s., and $F(1,100)$ $=.64$, n.s. 


\section{CHAPTER 5. DISCUSSION}

Informed by Self-Determination Theory and theories of parental involvement, the present study investigated the links between parental involvement and adolescent academic outcomes. Previous literature has offered mixed findings regarding these links, prompting the investigation of potential nonlinear associations among parental involvement, academic achievement, and intrinsic motivation. Findings in extant literature have not been clear as to whether or not greater amounts of home-based involvement and academic socialization are always beneficial for adolescents (e.g., Pomerantz, et al., 2005). Findings from this study suggest that parental involvement is not associated with academic achievement, as has been found in other studies (Hill \& Tyson, 2009). However, parental involvement was linked to intrinsic motivation. More specifically, the association between academic socialization and intrinsic motivation was nonlinear, whereas the association between home-based involvement and intrinsic motivation was linear. This study did not find evidence of age-related differences in these associations.

Contrary to the first two hypotheses of this study, neither home-based involvement nor academic socialization was associated with academic achievement. These findings, however, are in line with previous studies that found home-based 
involvement was not related to academic achievement (Karbach et al., 2013; Spera, 2006). The non-significant findings may indicate that finer distinctions should be made in terms of home-based involvement measures. Some scholars have noted that particular aspects of home-based involvement may differentially associate with academic outcomes (Hill \& Tyson, 2009). For example, homework help may affect adolescent achievement differently than other aspects of home-based involvement such as parents' knowledge about school performance or problems at school. Exploratory analyses in the present study provided some support for these differential effects - homework help was associated with academic achievement and intrinsic motivation, whereas the other form of home-based involvement tapping parent-child communication about school was not. Future studies should further examine this distinction in order to better understand how different facets of home-based involvement may be associated with academic outcomes. Regarding academic socialization, findings are contrary to studies that reported academic socialization was positively associated with academic achievement (e.g., Hill \& Tyson, 2009; Marchant et al., 2001). The lack of association (either linear or nonlinear) between academic socialization and academic achievement was surprising given that scholars have noted that academic socialization may be the most developmentally appropriate form of parental involvement because of adolescents' increasing desire for less intrusive forms of involvement (Hill \& Tyson, 2009; Hoover-Dempsey, et al., 2009). This conclusion, however, has been drawn from studies consisting mostly of white adolescents. There may be racial differences in what adolescents consider as intrusive strategies versus non-intrusive strategies. For example, cultural values that emphasize harmony, communalism, hierarchy between parents and children, and the value placed on 
obedience and respect toward elders among African American and Latino families (Boykin et al., 1997; Garcia Coll et al., 1995) suggest that parenting practices considered to be intrusive may differ across cultures. Therefore, non-significant findings may be an indication of un-modeled factors that would help to better capture the association between academic socialization and academic achievement. For example, race was the strongest predictor of GPA in the academic socialization model. Even though exploratory analyses in this study revealed no differences in associations based on adolescent race, future studies should continue to investigate whether the links between academic socialization and GPA vary across racial and ethnic groups. Further, although academic socialization was positively correlated with GPA, the relatively small sample size may have limited the power with which small effect sizes could have been detected as statistically significant.

Finally, the lack of association between parental involvement and academic achievement may reflect the notion that parents' involvement strategies are not directly related to adolescent performance in school. As Grolnick and Slowiaczek (1994) proposed, it is plausible that parents' involvement strategies operate indirectly via adolescents' perceived competence, rather than directly, to affect adolescent performance. Bivariate correlations in the present study suggest that this may be the case; both types of involvement were significantly associated with adolescents' perceptions of academic competence, which was one of the strongest predictors of GPA. Modeling this indirect association is an important step for future studies. It is also important to note that this study only included one semester GPA as a measure of academic achievement. Previous studies have shown that there are varying effect sizes for the association between 
involvement and different measures of academic achievement, such as standardized test scores or individual subject-area performance (Desimone, 1999; Jeynes, 2003). Future studies, therefore, should include multiple measures of academic achievement when available to better understand this association.

The positive linear association between home-based involvement and intrinsic motivation was not attenuated at high levels of involvement, contrary to hypothesis 3 . This is particularly surprising given that home-based involvement has been considered by scholars as more likely to undermine adolescent autonomy than academic socialization (Hoover-Dempsey et al., 2009). This finding, however, is consistent with Spera's (2006) study of $7^{\text {th }}$ and $8^{\text {th }}$ grade students that found a positive association between home-based involvement and intrinsic motivation.

As hypothesized, the positive association between academic socialization and intrinsic motivation was attenuated at high levels of academic socialization. This finding advances our understanding of the association between academic socialization and intrinsic motivation, as previous literature has focused primarily on linear associations. This finding supports theoretical perspectives suggesting that more involvement may not always benefit adolescents (e.g., Hoover-Dempsey \& Sandler, 1995; Pomerantz, 2007). Future studies should explore the mechanisms that explain the nonlinear association between parental involvement and motivation. For example, as suggested by SelfDetermination Theory (Ryan \& Deci, 2000), high levels of academic socialization may undermine adolescent autonomy, which in turn decreases intrinsic motivation.

Overall, these findings suggest that while more academic socialization may not always be beneficial for adolescents' intrinsic motivation, more home-based involvement 
may be consistently beneficial. Why might academic socialization and home-based involvement be related to motivation in different ways? One important consideration is parents' uses of different involvement strategies depending on adolescents' previous levels of intrinsic motivation. Parents of more intrinsically motivated adolescents may not feel the need to communicate the value of an education as much as parents whose adolescents are less intrinsically motivated. When considering home-based involvement, it may instead be the case that adolescents who are more intrinsically motivated may elicit more home-based support (i.e., ask their parents to be involved with schoolwork or freely share with parents about school) than adolescents who are less intrinsically motivated, explaining the linear association between intrinsic motivation and home-based involvement. It is important for future studies to consider prior levels of intrinsic motivation in an effort to empirically disentangle these associations.

Additionally, this study examined age-related differences in the associations among parental involvement, academic achievement, and intrinsic motivation. Findings suggest that there are not age differences in these associations (linear and nonlinear). The non-significant findings may be explained by the limited age-range of adolescents included in this sample, as well as the cross-sectional design of the present study. While middle school marks an important developmental time period to study parental involvement (Hill \& Taylor, 2004), it may provide too narrow of a window for viewing age effects. Additionally, a longitudinal design may allow for a more accurate representation of age effects. Findings in the present study did support previous literature reporting main effects for age as it relates to academic achievement (Barber \& Olsen, 2004; Gutman \& Midgley, 2000) such that an increase in age was associated with a 
decrease in GPA. However, age was unrelated to intrinsic motivation, which contradicts findings of previous studies (Corpus et al., 2009; Gottfried et al., 2001; Hayenga \& Corpus, 2010). It is important to note, however, that the bivariate correlation between age and intrinsic motivation was negative and statistically significant. This may indicate a direct link between age and intrinsic motivation that was too small to detect in the full model with a sample of this size.

Finally, though not intended as a focus of this study, findings interestingly showed significant links between parental involvement and intrinsic motivation, but not academic achievement. These findings suggest that parental involvement strategies are more likely to directly influence adolescents' thoughts and feelings about school and are less likely to affect adolescent school performance. Some scholars have noted that adolescents' thoughts and feelings about school may be the pathway through which involvement strategies are linked to school performance (e.g., Grolnick \& Slowiaczek, 1994). Therefore, future studies should consider using analytic methods that can simultaneously analyze both direct and indirect pathways among parental involvement, academic motivation, and school performance.

\section{$5.1 \quad \underline{\text { Limitations }}$}

This study provides interesting insight into the associations between two types of parental involvement and academic achievement and motivation, but there are several limitations to mention. First, this study used a cross-sectional design. With the exception of perceived academic competence, all study variables came from assessments in the spring semester. This prohibits the interpretation of causal relations, and limits the ability 
to fully investigate potential adolescent-driven associations between involvement and each outcome, particularly if these associations are dynamic and unfold over time. Additionally, although academic achievement was assessed from official school reports, this study relied primarily on adolescent reports of parental involvement and academic outcomes. Adolescent reports of these variables have been noted as reliable and valid in previous studies (e.g., Spera, 2006), but mono-reporter bias may have led to inflated associations between involvement and intrinsic motivation in the present study. This study also combined adolescents' reports of mothers' and fathers' home-based involvement in order to create the best match between reports of each type of involvement (data for academic socialization were not collected for mothers and father separately). These home-based involvement measures were significantly correlated, but it would be beneficial for future studies to separate mothers' and fathers' parenting practices in order to investigate potential differences in mothers' and fathers' involvement strategies and how they are linked to adolescent outcomes. Lastly, this study used a subsample of the original study in order to include GPA as an objective measure of academic achievement. This substantially reduced the sample size, which may have limited the power to detect statistically significant associations, particularly interaction effects when multiple additional variables were added to the analyses.

\section{$5.2 \quad \underline{\text { Implications }}$}

Despite these limitations, this study provides new insight into the associations between parental involvement and academic outcomes for adolescents by examining the possible nonlinear associations between parental involvement (i.e., home-based 
involvement and academic socialization) and adolescent academic outcomes (i.e., GPA and intrinsic motivation). Few previous studies have investigated home-based involvement and academic socialization as they relate to academic achievement and intrinsic motivation in the same sample; nonlinear associations have also not previously been analyzed.

Findings from this study have several implications for future research. The nonsignificant direct associations between parental involvement and GPA should prompt future researchers to consider indirect links between involvement and academic achievement to better understand how involvement is associated with achievement, particularly via perceived academic competence, as it was a strong predictor in all models in this study. It is also important for future studies to consider nonlinear associations. This study provides new evidence that the positive association between academic socialization and intrinsic motivation can be attenuated at high levels of involvement, although there was not overwhelming support for the confirmation of the nonlinear hypotheses (only one of the four hypothesized pathways was significant). It is still important to consider this nonlinear association as it may also exist for other adolescent outcomes such as school self-esteem or school trouble. 
REFERENCES 


\section{REFERENCES}

Aiken, L. S., \& West, S. G. (1991). Multiple regression: Testing and interpreting interactions. Thousand Oaks, CA: SAGE Publications, Inc.

Anguiano, R. P. V. (2004). Families and schools: The effect of parental involvement on high school completion. Journal of Family Issues, 25(1), 61-85. doi: 10.1177/0192513X03256805

Archibald, A. B., Graber, J. A. \& Brooks-Gunn, J. (2008). Pubertal processes and physiological growth in adolescence. In G.R. Adams \& M.D. Berzonsky (Eds). Blackwell handbook of adolescence. Oxford, UK: Blackwell Publishing Ltd. doi: 10.1002/9780470756607.ch2

Barber, B. K., \& Olsen, J. A. (2004). Assessing the transitions to middle and high school. Journal of Adolescent Research, 19(1), 3-30. doi: 10.1177/0743558403258113

Barnard, W. M. (2004). Parent involvement in elementary school and educational attainment. Children and Youth Services Review, 26(1), 39-62. doi: 10.1016/j.childyouth.2003.11.002

Boykin, A. W., Jagers, R. J., Ellison, C. M., \& Albury, A. (1997). Communalism: Conceptualization and measurement of an Afrocultural social orientation. Journal of Black Studies, 409-418. 
Casey, B. J., Getz, S., \& Galvan, A. (2008). The adolescent brain. Developmental Review, 28, 62-77. doi: 10.1016/j.dr.2007.08.003

Cheung, C. S. S., \& Pomerantz, E. M. (2012). Why does parents' involvement enhance children's achievement? The role of parent-oriented motivation. Journal of Educational Psychology, 104(3), 820-832. doi: 10.1037/a0027183

Cohen, J., Cohen, P., West, S. G., \& Aiken, L. S. (2003). Applied multiple regression/correlation analysis for the behavior sciences. Mahwah, NJ: Erlbaum.

Corpus, J. H., McClintic-Gilbert, M. S., \& Hayenga, A. O. (2009). Within-year changes in children's intrinsic and extrinsic motivational orientations: Contextual predictors and academic outcomes. Contemporary Educational Psychology, 34(2), 154-166. doi: 10.1016/j.cedpysch.2009.01.001

Deci, E. L., Vallerand, R. J., Pelletier, L. G., \& Ryan, R. M. (1991). Motivation and education: The self-determination perspective. Educational Psychologist, 26(3-4), $325-346$.

Desimone, L. (1999). Linking parent involvement with student achievement: Do race and income matter? The Journal of Educational Research, 93, 11-30. doi: $10.1080 / 00220679909597625$

Domina, T. (2005). Leveling the home advantage: Assessing the effectiveness of parental involvement in elementary school. Sociology of Education, 78(3), 233-249. doi: $10.1177 / 003804070507800303$

Dotterer, A. M., Lowe, K., \& McHale, S. M. (2013). Academic growth trajectories and family relationships among african american youth. Journal of Research on Adolescence. doi: 10.1111/jora.12080 
Duckworth, A. L., \& Seligman, M. E. (2006). Self-discipline gives girls the edge: Gender in self-discipline, grades, and achievement test scores. Journal of Educational Psychology, 98(1), 198-208. doi: 10.1037/0022-0663.98.1.198

Eccles, J. S. \& Harold, R. D. (1996). Family involvement in children's and adolescents' schooling. In A. Booth \& J. F. Dunn (Eds.), Family-school links: How do they affect educational outcomes? (pp. 3-34). Mahwah, NJ: Erlbaum.

Eccles, J. S. \& Roeser, R. W. (2009). Schools, academic motivation, and stageenvironment fit. In R. M. Lerner, \& L. Steinberg (Eds.), Handbook of adolescent psychology (pp. 404-434). Hoboken, NJ: John Wiley \& Sons.

Epstein, J. L. (2001). School, family, and community partnerships: Preparing educators and improving schools. Boulder, CO: Westview Press.

Fan, X., \& Chen, M. (2001). Parental involvement and students' academic achievement: A meta-analysis. Educational Psychology Review, 13(1), 1-22. doi: 10.1023/A:1009048817385

Fan, W., \& Williams, C. M. (2010). The effects of parental involvement on students' academic self-efficacy, engagement and intrinsic motivation. Educational Psychology, 30(1), 53-74. doi: 10.1080/01443410903353302

Garcia Coll, C. T., Meyer, E. C., \& Brillon, L. (1995). Ethnic and minority parenting. In M. H. Bornstein (Ed.), Handbook of parenting: Biology and ecology of parenting (pp. 189-209). Hillsdale, NJ: Lawrence Erlbaum Associates, Inc.

Ginsburg, G. S., \& Bronstein, P. (1993). Family factors related to children's intrinsic/extrinsic motivational orientation and academic performance. Child Development, 64, 1461-1474. doi: 10.2307/1131546 
Gonzalez-DeHass, A. R., Willems, P. P., \& Holbein, M. F. D. (2005). Examining the relationship between parental involvement and student motivation. Educational Psychology Review, 17(2), 99-123. doi: 10.1007/s10648-3949-7

Gottfried, A. E., Fleming, J. S., \& Gottfried, A. W. (2001). Continuity of academic intrinsic motivation from childhood through late adolescence: A longitudinal study. Journal of Educational Psychology, 93(1), 3. doi:

10.1037/0022-0663.93.1.3

Grolnick, W. S., \& Slowiaczek, M. L. (1994). Parents' involvement in children's schooling: A multidimensional conceptualization and motivational model. Child Development, 65, 237-252. doi: 10.1111/j.1467-8624.1994.tb00747.x

Gutman, L. M., \& Midgley, C. (2000). The role of protective factors in supporting the academic achievement of poor African American students during the middle school transition. Journal of Youth and Adolescence, 29(2), 223-249. doi:

10.1023/A:1005108700243

Hill, N. E., Castellino, D. R., Lansford, J. E., Nowlin, P., Dodge, K. A., Bates, J. E., \& Pettit, G. S. (2004). Parent academic involvement as related to school behavior, achievement, and aspirations: Demographic variations across adolescence. Child Development, 75(5), 1491-1509. doi: 10.1111/j.1467-8624.2004.00753.x

Hill, N. E., \& Chao, R. K. (2009). Background in theory, practice, and policy. In N.E. Hill \& R. K. Chao (Eds.), Families, schools, and the adolescent (pp. 1-15). New York, NY: Teachers College Press. 
Hill, N. E., \& Taylor, L. C. (2004). Parental school involvement and children's academic achievement pragmatics and issues. Current Directions in Psychological Science, 13(4), 161-164. doi: 10.1111/j.0963-7214.2004.00298.x

Hill, N. E., \& Tyson, D. F. (2009). Parental involvement in middle school: a metaanalytic assessment of the strategies that promote achievement. Developmental Psychology, 45(3), 740-763. doi: 10.1037/a0015362

Hill, N. E., Tyson, D. F., \& Bromell, L. (2009). Developmentally appropriate strategies across ethnicity and socioeconomic status. In N.E. Hill \& R. K. Chao (Eds.), Families, schools, and the adolescent (pp. 53-72). New York, NY: Teachers College Press.

Hoover-Dempsey, K. V., Ice, C. L., \& Whitaker, M. C. (2009). We're way past reading together: Why and how parental involvement in adolescence makes sense. In N.E. Hill \& R. K. Chao (Eds.), Families, schools, and the adolescent (pp. 19-36). New York, NY: Teachers College Press.

Hoover-Dempsey, K., \& Sander, H. (1995). Parental involvement in children's education: Why does it make a difference. The Teachers College Record, 97(2), 310-331.

Institute of Education Sciences; National Center for Education Statistics. (2011). [Graph illustration of Grade 8 National Results - Achievement Levels]. The Nation's Report Card. Retrieved from http://nationsreportcard.gov/

Jacobs, J. E., Lanza, S., Osgood, D. W., Eccles, J. S., \& Wigfield, A. (2002). Changes in children's self-competence and values: Gender and domain differences across grades one through twelve. Child Development, 73(2), 509-527. doi:

$10.1111 / 1467-8624.00421$ 
Jeynes, W. H. (2003). A meta-analysis the effects of parental involvement on minority children's academic achievement. Education and Urban Society, 35(2), 202-218. doi: $10.1177 / 0013124502239392$

Jeynes, W. H. (2007). The relationship between parental involvement and urban secondary school student academic achievement a meta-analysis. Urban Education, 42(1), 82-110. doi: 10.1177/0042085906293818

Jeynes, W. H. (2012). A meta-analysis of the efficacy of different types of parental involvement programs for urban students. Urban Education, 47(4), 706-742. doi: $10.1177 / 0042085912445643$

Karbach, J., Gottschling, J., Spengler, M., Hegewald, K., \& Spinath, F. M. (2013). Parental involvement and general cognitive ability as predictors of domainspecific academic achievement in early adolescence. Learning and Instruction, 23, 43-51. doi: 10.1016/j.learninstruc.2012.09.004

Lepper, M. R., Corpus, J. H., \& Iyengar, S. S. (2005). Intrinsic and extrinsic motivational orientations in the classroom: Age differences and academic correlates. Journal of Educational Psychology, 97, 184-196. doi: $10.1037 / 0022-0663.97 .2 .184$

Marchant, G. J., Paulson, S. E., \& Rothlisberg, B. A. (2001). Relations of middle school students' perceptions of family and school contexts with academic achievement. Psychology in the Schools, 38(6), 505-519. doi: 10.1002/pits.1039

McNeal Jr, R. B. (2012). Checking in or checking out? Investigating the parent involvement reactive hypothesis. The Journal of Educational Research, 105(2), 79-89. doi: $10.1080 / 00220671.2010 .519410$ 
Milgram, N., \& Toubiana, Y. (1999). Academic anxiety, academic procrastination, and parental involvement in students and their parents. British Journal of Educational Psychology, 69(3), 345-361. doi: 10.1348/000709999157761

Muller, C. (1998). Gender differences in parental involvement and adolescents' mathematics achievement. Sociology of Education, 336-356.

Murdock, T. B. (1999). The social context of risk: Status and motivational predictors of alienation in middle school. Journal of Educational Psychology, 91, 62-75. doi: $10.1037 / 0022-0663.91 .1 .62$

Pomerantz, E. M., Altermatt, E. R., \& Saxon, J. L. (2002). Making the grade but feeling distressed: Gender differences in academic performance and internal distress. Journal of Educational Psychology, 94(2), 396-404. doi: 10.1037/00220663.94 .2 .396

Pomerantz, E. M., Moorman, E. A., \& Litwack, S. D. (2007). The how, whom, and why of parents' involvement in children's academic lives: More is not always better. Review of Educational Research, 77, 373-410. doi: 10.3102/00346530305567

Ryan, R. M., \& Deci, E. L. (2000). Intrinsic and extrinsic motivations: Classic definitions and new directions. Contemporary Educational Psychology, 25(1), 54-67. doi: 10.1006/ceps. 1999.1020

Ryan, R. M., \& Deci, E. L. (2000). Self-determination theory and the facilitation of intrinsic motivation, social development, and well-being. American Psychologist, 55(1), 68. doi: 10.1037/0003-066X.55.1.68

Schunk, D. H., Pintrich, P. R., \& Meece, J. R. (2008). Motivation in education: Theory, research and applications. Upper Saddle River, NJ: Pearson Education Inc. 
Sirin, S. R., \& Rogers-Sirin, L. (2004). Exploring school engagement of middle-class African American adolescents. Youth \& Society, 35(3), 323-340. doi: $10.1177 / 0044118 X 03255006$

Spera, C. (2005). A review of the relationship among parenting practices, parenting styles, and adolescent school achievement. Educational Psychology Review, 17(2), 125146. doi: $10.1007 / \mathrm{s} 10648-005-3950-1$

Spera, C. (2006). Adolescents' perceptions of parental goals, practices, and styles in relation to their motivation and achievement. The Journal of Early Adolescence, 26(4), 456-490. doi: 10.1177/0272431606291940

Steinberg, L. (2001). We know some things: Parent-adolescent relationships in retrospect and prospect. Journal of Research on Adolescence, 11, 1-19. doi: $10.1111 / 1532-7795.00001$

Van Voorhis, F. L. (2011). Costs and benefits of family involvement in homework. Journal of Advanced Academics, 22, 220-249. doi: $10.1177 / 1932202 X 1102200203$

Wang, J., \& Goldschmidt, P. (2003). Importance of middle school mathematics on high school students' mathematics achievement. The Journal of Educational Research, 97(1), 3-17. doi: 10.1080/00220670309596624

Wehmeyer, M. L., Abery, B. H., Mithaug, D. E., \& Stancliffe, R. J. (2003). Theory in self-determination: Foundation for educational practice. Springfield, IL: Charles C. Thomas, Publisher Ltd. 
Yan, W., \& Lin, Q. (2005). Parent involvement and mathematics achievement: Contrast across racial and ethnic groups. The Journal of Educational Research, 99(2), 116127. doi: 10.3200/JOER.99.2.116 
APPENDICES 


\section{Appendix A Tables}

Table 1

Correlations and Descriptive Statistics $(N=102)$

\begin{tabular}{|c|c|c|c|c|c|c|c|}
\hline Variables & 1 & 2 & 3 & 4 & 5 & 6 & 7 \\
\hline $\begin{array}{l}\text { 1. Perceived academic } \\
\text { competence }\end{array}$ & - & & & & & & \\
\hline 2. Parent education level ${ }^{\mathrm{a}}$ & .12 & - & & & & & \\
\hline 3. Adolescent age & -.13 & -.02 & - & & & & \\
\hline 4. Academic socialization & $.26^{* *}$ & $.23 *$ & .01 & - & & & \\
\hline $\begin{array}{l}\text { 5. Home-based } \\
\text { involvement }\end{array}$ & $.20^{*}$ & -.04 & .01 & .19 & - & & \\
\hline 6. Intrinsic motivation & $.58 * * *$ & .02 & $-.20 *$ & $.23 *$ & $.31 * *$ & - & \\
\hline 7. Semester 2 GPA & $.45 * * *$ & .18 & $-.27 * *$ & .16 & -.07 & $.35^{* * *}$ & - \\
\hline$M$ & 28.29 & 3.31 & 13.00 & 4.36 & 2.45 & 3.46 & 2.92 \\
\hline$S D$ & 4.49 & 1.01 & .93 & .50 & .39 & .63 & .73 \\
\hline${ }^{\mathrm{a}} N=96$ & & & & & & & \\
\hline
\end{tabular}


Table 2

Summary of Final Regression Analyses Predicting Grade Point Average (GPA) and Intrinsic Motivation as a Function of Home-based Involvement $(N=102)$

\begin{tabular}{|c|c|c|c|c|c|c|}
\hline \multirow[b]{2}{*}{ Variable } & \multicolumn{3}{|c|}{ GPA } & \multicolumn{3}{|c|}{ Intrinsic Motivation } \\
\hline & $B$ & $S E B$ & $\beta$ & $B$ & $S E B$ & $\beta$ \\
\hline Intercept & 2.78 & .08 & & 3.42 & .07 & \\
\hline $\begin{array}{l}\text { Perceived academic } \\
\text { competence }\end{array}$ & .07 & .01 & $.42 * * *$ & .07 & .01 & $.53 * * *$ \\
\hline Race $^{\mathrm{a}}$ & .69 & .14 & $.38 * * *$ & .11 & .12 & .08 \\
\hline Age & -.18 & .06 & $-.23 * *$ & -.09 & .05 & -.14 \\
\hline $\begin{array}{l}\text { Home-based } \\
\text { involvement }\end{array}$ & -.24 & .16 & -.13 & .37 & .14 & $.23^{*}$ \\
\hline $\begin{array}{l}\text { Home-based } \\
\text { involvement }^{2}\end{array}$ & -.01 & .29 & -.00 & .12 & .26 & .04 \\
\hline$R^{2}$ & & .41 & & & .40 & \\
\hline$F$ for change in $R^{2}$ & & .00 & & & .23 & \\
\hline
\end{tabular}

Note. Perceived academic abilities, age, and home-based involvement were centered at their means.

${ }^{\mathrm{a}}$ Race: 0 = non-white, $1=$ white.

$* p<.05 . * * p<.01 . * * * p<.001$. 
Table 3

Summary of Final Regression Analyses Predicting Grade Point Average (GPA) and Intrinsic Motivation as a Function of Academic Socialization $(N=102)$

\begin{tabular}{|c|c|c|c|c|c|c|}
\hline \multirow[b]{2}{*}{ Variable } & \multicolumn{3}{|c|}{ GPA } & \multicolumn{3}{|c|}{ Intrinsic Motivation } \\
\hline & $B$ & $S E B$ & $\beta$ & $B$ & $S E B$ & $\beta$ \\
\hline Intercept & 2.76 & .08 & & 3.51 & .07 & \\
\hline $\begin{array}{l}\text { Perceived academic } \\
\text { competence }\end{array}$ & .06 & .01 & $.38 * * *$ & .07 & .01 & $.52 * * *$ \\
\hline $\operatorname{Race}^{\mathrm{a}}$ & .70 & .14 & $.39 * * *$ & .11 & .12 & .07 \\
\hline Age & -.18 & .06 & $-.23 * *$ & -.10 & .05 & -.14 \\
\hline Academic & .12 & .14 & .08 & -.02 & .12 & -.01 \\
\hline socialization & & & & & & \\
\hline Academic & .06 & .18 & .03 & -.31 & .16 & $-.20 *$ \\
\hline socialization $^{2}$ & & & & & & \\
\hline$R^{2}$ & & .40 & & & .39 & \\
\hline$F$ for change in $R^{2}$ & & .12 & & & $4.01 *$ & \\
\hline
\end{tabular}

Note. Perceived academic abilities, age, and academic socialization were centered at their means.

${ }^{\mathrm{a}}$ Race: $0=$ non-white, $1=$ white.

$* p<.05 . * * p<.01 . * * * p<.001$. 
Appendix B Figures

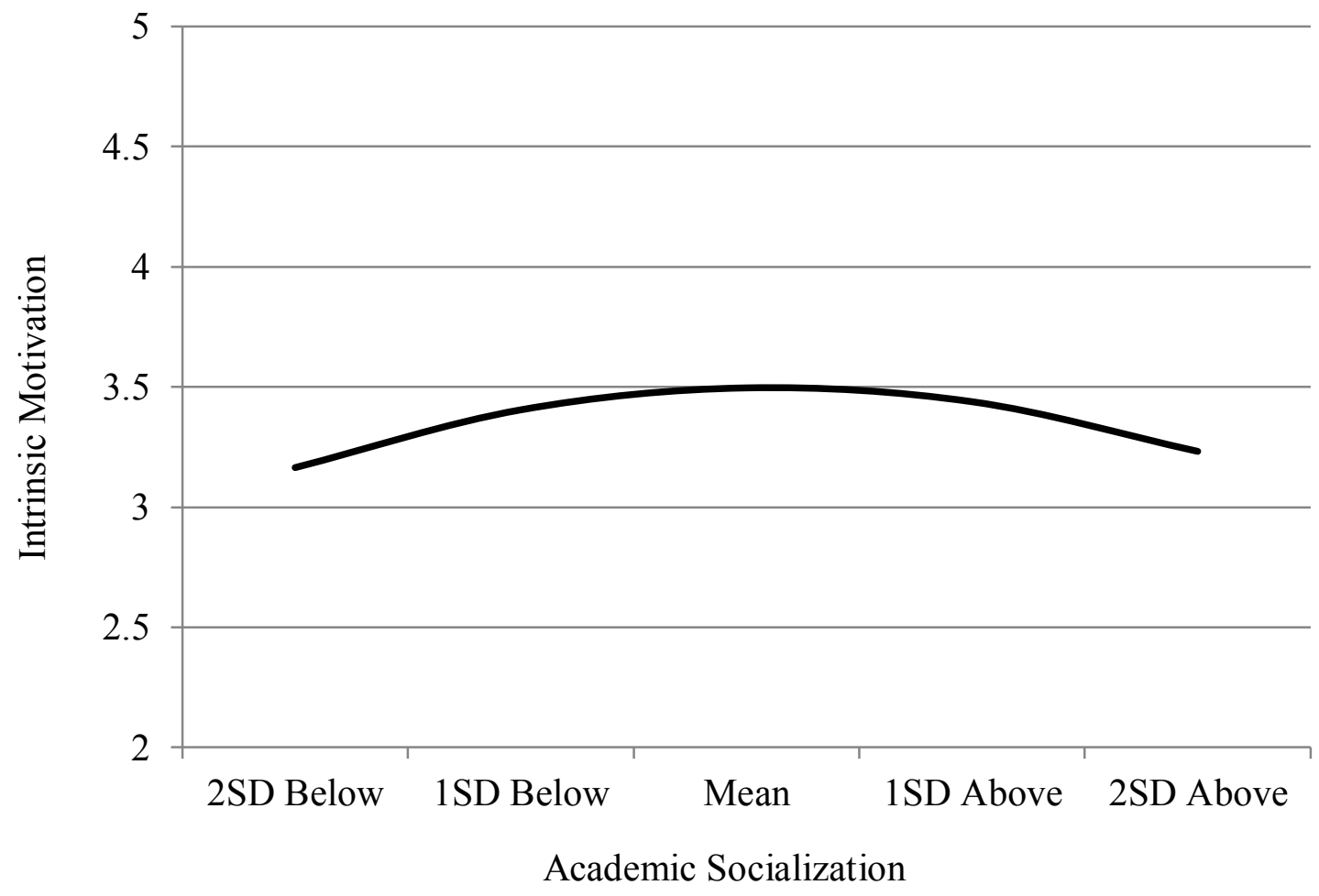

Figure 1. The nonlinear association between academic socialization and intrinsic motivation.

Note $. \mathrm{SD}=$ Standard deviation 
Appendix C Survey Items

\begin{tabular}{|l|l|}
\hline \multicolumn{2}{|c|}{ Home-based Involvement } \\
\hline Question & Scale \\
\hline Helps with homework when I ask. & 1 (Never) \\
& 2 (Sometimes) \\
& 3 (Always) \\
\hline Knows how I am doing in school. & 1 (Never) \\
& 2 (Sometimes) \\
& 3 (Always) \\
\hline Helps me with my schoolwork. & 1 (Never) \\
& 2 (Sometimes) \\
& 3 (Always) \\
\hline Talks with me about problems I'm & 1 (Never) \\
having in school. & 2 (Sometimes) \\
& 3 (Always) \\
\hline Checks my homework after it is & 1 (Never) \\
completed, (checking that it's done & 2 (Sometimes) \\
correctly, or proofreading reports). & 3 (Always) \\
\hline Talks to me about what I'm learning in & 1 (Never) \\
school. & 2 (Sometimes) \\
& 3 (Always) \\
\hline
\end{tabular}

Note: Identical questions were asked about mothers and fathers. 


\begin{tabular}{|c|c|}
\hline \multicolumn{2}{|c|}{ Academic Socialization } \\
\hline Question & Scale \\
\hline $\begin{array}{l}\text { My parents tell me that many of the } \\
\text { things I learn in school will be useful in } \\
\text { the future. }\end{array}$ & $\begin{array}{l}1 \text { (Strongly disagree) } \\
2 \text { (Somewhat disagree) } \\
3 \text { (Neither agree nor disagree) } \\
4 \text { (Somewhat agree) } \\
5 \text { (Strongly agree) }\end{array}$ \\
\hline $\begin{array}{l}\text { My parents tell me that an education will } \\
\text { help me earn a good living. }\end{array}$ & $\begin{array}{l}1 \text { (Strongly disagree) } \\
2 \text { (Somewhat disagree) } \\
3 \text { (Neither agree nor disagree) } \\
4 \text { (Somewhat agree) } \\
5 \text { (Strongly agree) }\end{array}$ \\
\hline $\begin{array}{l}\text { My parents tell me that if I work hard in } \\
\text { school, I will get a better job than the } \\
\text { kids who don't try hard. }\end{array}$ & $\begin{array}{l}1 \text { (Strongly disagree) } \\
2 \text { (Somewhat disagree) } \\
3 \text { (Neither agree nor disagree) } \\
4 \text { (Somewhat agree) } \\
5 \text { (Strongly agree) }\end{array}$ \\
\hline $\begin{array}{l}\text { My parents tell me that I can earn a good } \\
\text { living even if I do not have a good } \\
\text { education. }\end{array}$ & $\begin{array}{l}1 \text { (Strongly disagree) } \\
2 \text { (Somewhat disagree) } \\
3 \text { (Neither agree nor disagree) } \\
4 \text { (Somewhat agree) } \\
5 \text { (Strongly agree) }\end{array}$ \\
\hline $\begin{array}{l}\text { My parents tell me that I will make more } \\
\text { money someday if I do well in school. }\end{array}$ & $\begin{array}{l}1 \text { (Strongly disagree) } \\
2 \text { (Somewhat disagree) } \\
3 \text { (Neither agree nor disagree) } \\
4 \text { (Somewhat agree) } \\
5 \text { (Strongly agree) }\end{array}$ \\
\hline $\begin{array}{l}\text { My parents tell me that people can do } \\
\text { well in life without an education. }\end{array}$ & $\begin{array}{l}1 \text { (Strongly disagree) } \\
2 \text { (Somewhat disagree) } \\
3 \text { (Neither agree nor disagree) } \\
4 \text { (Somewhat agree) } \\
5 \text { (Strongly agree) }\end{array}$ \\
\hline $\begin{array}{l}\text { My parents tell me that getting a good } \\
\text { education should be my top priority. }\end{array}$ & $\begin{array}{l}1 \text { (Strongly disagree) } \\
2 \text { (Somewhat disagree) } \\
3 \text { (Neither agree nor disagree) } \\
4 \text { (Somewhat agree) } \\
5 \text { (Strongly agree) }\end{array}$ \\
\hline $\begin{array}{l}\text { My parents tell me that I will get paid } \\
\text { what I deserve if I earn good grades in } \\
\text { school. }\end{array}$ & $\begin{array}{l}1 \text { (Strongly disagree) } \\
2 \text { (Somewhat disagree) } \\
3 \text { (Neither agree nor disagree) } \\
4 \text { (Somewhat agree) } \\
5 \text { (Strongly agree) }\end{array}$ \\
\hline
\end{tabular}




\begin{tabular}{|c|c|}
\hline \multicolumn{2}{|c|}{ Intrinsic Motivation } \\
\hline Question & Scale \\
\hline $\begin{array}{l}\text { I like school subjects that challenge me to } \\
\text { think hard and figure things out. }\end{array}$ & $\begin{array}{l}1 \text { (Never) } \\
2 \text { (A Few Times) } \\
3 \text { (Sometimes) } \\
4 \text { (Often) } \\
5 \text { (Always) }\end{array}$ \\
\hline I like hard work because it's a challenge. & $\begin{array}{l}1 \text { (Never) } \\
2 \text { (A Few Times) } \\
3 \text { (Sometimes) } \\
4 \text { (Often) } \\
5 \text { (Always) }\end{array}$ \\
\hline $\begin{array}{l}\text { I do extra projects because I can learn about } \\
\text { things that interest me. }\end{array}$ & $\begin{array}{l}1 \text { (Never) } \\
2 \text { (A Few Times) } \\
3 \text { (Sometimes) } \\
4 \text { (Often) } \\
5 \text { (Always) }\end{array}$ \\
\hline I like to learn as much as I can in school. & $\begin{array}{l}1 \text { (Never) } \\
2 \text { (A Few Times) } \\
3 \text { (Sometimes) } \\
4 \text { (Often) } \\
5 \text { (Always) }\end{array}$ \\
\hline $\begin{array}{l}\text { I like to try to figure out how to do school } \\
\text { assignments on my own. }\end{array}$ & $\begin{array}{l}1 \text { (Never) } \\
2 \text { (A Few Times) } \\
3 \text { (Sometimes) } \\
4 \text { (Often) } \\
5 \text { (Always) }\end{array}$ \\
\hline $\begin{array}{l}\text { I work really hard because I really like to } \\
\text { learn new things. }\end{array}$ & $\begin{array}{l}1 \text { (Never) } \\
2 \text { (A Few Times) } \\
3 \text { (Sometimes) } \\
4 \text { (Often) } \\
5 \text { (Always) }\end{array}$ \\
\hline $\begin{array}{l}\text { I ask questions in class because I want to } \\
\text { learn new things. }\end{array}$ & $\begin{array}{l}1 \text { (Never) } \\
2 \text { (A Few Times) } \\
3 \text { (Sometimes) } \\
4 \text { (Often) } \\
5 \text { (Always) }\end{array}$ \\
\hline $\begin{array}{l}\text { I work on problems to learn how to solve } \\
\text { them. }\end{array}$ & $\begin{array}{l}1 \text { (Never) } \\
2 \text { (A Few Times) } \\
3 \text { (Sometimes) } \\
4 \text { (Often) } \\
5 \text { (Always) }\end{array}$ \\
\hline $\begin{array}{l}\text { If I get stuck on a problem I keep trying to } \\
\text { figure out the problem on my own. }\end{array}$ & $\begin{array}{l}1 \text { (Never) } \\
2 \text { (A Few Times) } \\
3 \text { (Sometimes) } \\
4 \text { (Often) } \\
5 \text { (Always) }\end{array}$ \\
\hline
\end{tabular}




\begin{tabular}{|c|c|}
\hline \multicolumn{2}{|c|}{ Intrinsic Motivation (continued) } \\
\hline $\begin{array}{l}\text { When I make a mistake I like to figure out } \\
\text { the right answer by myself. }\end{array}$ & $\begin{array}{l}1 \text { (Never) } \\
2 \text { (A Few Times) } \\
3 \text { (Sometimes) } \\
4 \text { (Often) } \\
5 \text { (Always) }\end{array}$ \\
\hline $\begin{array}{l}\text { I like difficult school work because I find it } \\
\text { more interesting. }\end{array}$ & $\begin{array}{l}1 \text { (Never) } \\
2 \text { (A Few Times) } \\
3 \text { (Sometimes) } \\
4 \text { (Often) } \\
5 \text { (Always) }\end{array}$ \\
\hline $\begin{array}{l}\text { I like to move on to new work that's at a } \\
\text { more difficult level. }\end{array}$ & $\begin{array}{l}1 \text { (Never) } \\
2 \text { (A Few Times) } \\
3 \text { (Sometimes) } \\
4 \text { (Often) } \\
5 \text { (Always) }\end{array}$ \\
\hline I like to do my schoolwork without help. & $\begin{array}{l}1 \text { (Never) } \\
2 \text { (A Few Times) } \\
3 \text { (Sometimes) } \\
4 \text { (Often) } \\
5 \text { (Always) }\end{array}$ \\
\hline $\begin{array}{l}\text { I like difficult problems because I enjoy } \\
\text { trying to figure them out. }\end{array}$ & $\begin{array}{l}1 \text { (Never) } \\
2 \text { (A Few Times) } \\
3 \text { (Sometimes) } \\
4 \text { (Often) } \\
5 \text { (Always) }\end{array}$ \\
\hline $\begin{array}{l}\text { I do my schoolwork to find out about a lot } \\
\text { of things I've been wanting to know. }\end{array}$ & $\begin{array}{l}1 \text { (Never) } \\
2 \text { (A Few Times) } \\
3 \text { (Sometimes) } \\
4 \text { (Often) } \\
5 \text { (Always) }\end{array}$ \\
\hline $\begin{array}{l}\text { I read things because I am interested in the } \\
\text { subject. }\end{array}$ & $\begin{array}{l}1 \text { (Never) } \\
2 \text { (A Few Times) } \\
3 \text { (Sometimes) } \\
4 \text { (Often) } \\
5 \text { (Always) }\end{array}$ \\
\hline $\begin{array}{l}\text { When I don't understand something right } \\
\text { away I like to try to figure it out by myself. }\end{array}$ & $\begin{array}{l}1 \text { (Never) } \\
2 \text { (A Few Times) } \\
3 \text { (Sometimes) } \\
4 \text { (Often) } \\
5 \text { (Always) }\end{array}$ \\
\hline
\end{tabular}




\begin{tabular}{|l|l|}
\hline \multicolumn{2}{|c|}{ Perceived Competence - Math } \\
\hline Question & Scale \\
\hline How good at math are you? & $1-$ Not at all good \\
& 2 \\
& 3 \\
& $4-$ OK \\
& 5 \\
& 6 \\
& $7-$ Very good \\
\hline How well do you expect to do in math & $1-$ Not at all well \\
this year? & 2 \\
& 3 \\
& $4-$ OK \\
& 5 \\
& 6 \\
\hline How good would you be at learning & $7-$ Very well \\
something new in math? & $1-$ Not at all good \\
& 2 \\
& 3 \\
& $4-$ OK \\
\hline In general, how useful is what you learn & 6 \\
in math? & $7-$ Not at all useful \\
& 2 \\
& 3 \\
\hline For me, being good at math is & 4 \\
& 5 \\
& 6 \\
& $7-$ Very useful \\
\hline & $2-$ Not at all important \\
& 3 \\
& 4 \\
& 5 \\
& 6 \\
& $7-$ Very important \\
\hline
\end{tabular}




\begin{tabular}{|c|c|}
\hline \multicolumn{2}{|c|}{ Perceived Competence - English } \\
\hline Question & Scale \\
\hline How good at reading are you? & $\begin{array}{l}1-\text { Not at all good } \\
2 \\
3 \\
4-\text { OK } \\
5 \\
6 \\
7-\text { Very good }\end{array}$ \\
\hline $\begin{array}{l}\text { How well do you expect to do in English } \\
\text { class this year? }\end{array}$ & $\begin{array}{l}1-\text { Not at all well } \\
2 \\
3 \\
4-\mathrm{OK} \\
5 \\
6 \\
7-\text { Very well }\end{array}$ \\
\hline $\begin{array}{l}\text { How good would you be at learning } \\
\text { something new in English class? }\end{array}$ & $\begin{array}{l}1-\text { Not at all good } \\
2 \\
3 \\
4-\text { OK } \\
5 \\
6 \\
7-\text { Very good }\end{array}$ \\
\hline $\begin{array}{l}\text { In general, how useful is what you learn } \\
\text { in English class? }\end{array}$ & $\begin{array}{l}1-\text { Not at all useful } \\
2 \\
3 \\
4 \\
5 \\
6 \\
7-\text { Very useful }\end{array}$ \\
\hline For me, being good at reading is & $\begin{array}{l}1-\text { Not at all important } \\
2 \\
3 \\
4 \\
5 \\
6 \\
7 \text { - Very important }\end{array}$ \\
\hline
\end{tabular}

